\title{
The "Albatross" of Immigration Reform: Temporary Worker Policy in the United States
}

\author{
Vernon M. Briggs, Jr. \\ Cornell University
}

Temporary worker policy in the United States traditionally has been advocated as a means to meet shortages for labor - a demand problem. Over the past decade, however, there has been support for the use of such policies as a means of addressing illegal immigration - a supply problem. Despite the fact that experiences show that such endeavors actually foster illegal immigration, the drive for immigration reform in the 1980s was seriously encumbered with a variety of attempts both to expand existing and to add new temporary worker programs. This article reviews the evolution of temporary worker policy and indicates how efforts to admit more temporary workers complicated the immigration reform process. Indeed, it was not until the major temporary worker proposals were finally removed from the Simpson-Rodino Act - by the adoption of a highly controversial "second amnesty" program (i.e., the Schumer Amendment) - that passage of legislation was achieved. Because this program functioned as a bargaining chip in the effort to establish a system of employer sanctions, it is unlikely that this expedient measure will set a precedent for future replication. Hence, it can be anticipated that efforts will eventually be made to revive temporary worker policy and, in the process, rekindle the debate over this contentious issue.

For almost as long as the United States has sought to enforce general restrictions on immigration, there have been parallel legal steps to make formal exceptions for the admission of temporary foreign workers. The legal formats have changed and the number of participants have fluctuated widely. Nonetheless, the concept has persevered. Indeed, on each of the three occasions in the 1980s when Congress has debated comprehensive immigration reform, the subject of temporary workers has arisen as a subject of bitter contention. Many opponents to the immigration reform bills of the 1980s were consistent in their positions by also opposing any effort to continue or to enlarge the extant temporary worker programs (e.g., organizations representing Hispanic groups). Other groups were willing to abandon their spposition if the temporary worker programs were liberalized or expanded 
(e.g., agricultural employers). Likewise, most strong supporters of immigration reform are adamantly opposed to temporary worker programs but were faced with the dilemma of accepting their inclusion as the price of passing the overall program (e.g., organized labor and the lobby group known as the Federation of Americans for Immigration Reform). Thus, temporary worker policy became an issue that made genuine immigration reform difficult. Indeed, the passage of the Immigration Reform and Control Act of 1986 (i.e., the Simpson-Rodino Act) was not possible until a myriad of pending temporary worker proposals were deleted and a "quick-fix" compromise (i.e., the Schumer Amendment), that permitted the regularization of the immigration status of hundreds of thousands of illegal immigrants who had worked in southwestern agriculture in 1986, was adopted.

In this political context, it has been impossible to debate the efficacy of temporary worker policy on the basis of its merits. Impartial discussion tends to collapse in the wake of political expediency. This intellectual dilemma however, should not mask the fact that, in the 1980s, both the basic rationale and the specific format of the temporary worker programs that were proposed represent a sharp departure from their historical precedents. Traditionally, temporary worker programs in the United States have been designed to respond to shortages of labor - a demand problem. They were authorized during periods when the nation has been at war or on the verge of entering war. They were deemed necessary to meet short run labor bottlenecks when the labor force was expanding rapidly and unemployment was extremely low. The resulting programs usually have had numerous protections for both citizens and foreign workers built into their operational requirements although actual enforcement of these terms often left much to be desired.

In contrast, the proposals of the 1980s have been motivated largely by concern over the mass abuse of the nation's immigration system by illegal immigrants - a supply problem. The nation is not engaged in any military crisis nor is there any other evidence of a general shortage of unskilled manpower. To the contrary, the aggregate unemployment rate has consistently hovered in the seven percent or higher range with considerably higher rates prevailing for the subgroups of the labor force who generally provide workers for the nation's secondary labor markets. Furthermore, the designs of the proposed programs showed little concern for the welfare of either the participants or the citizen workers with whom they would compete.

Given this departure in mission and format, it is a propitious time to examine this critical element of the nation's labor and immigration policies.

\section{THE TRADITIONAL RATIONALE}

It is possible to argue that the roots of temporary worker policy in the United States extend back to the Civil War era. Although there are no official 
unemployment figures for this period, it is generally conceded to have been a time of extreme labor shortages. In response, President Abraham Lincoln requested in late 1863 and Congress adopted in early 1864 the Contract Labor Act. This legislation enabled private employers to recruit foreign workers and to pay their transportation expenses to the United States. The enlisted workers, in turn, were required to sign legally binding contracts whereby they pledged their wages for up to twelve months to employers to repay these transportation expenses. Often they were induced to sign contracts for additional years to defray their living expenses during the initial year. Due to these procedural features, the program was widely criticized and the law was ultimately repealed in 1868 . Contract labor, however, continued for many years afterward since the repeal of the law has not prohibited the actual practice. It was not until 1885 that the Alien Contract Law specifically banned such arrangements but, because of inadequate enforcement, the practice continued for years afterward.

Despite the surface features of the contract labor program, it did not technically constitute an antecedent to the temporary worker programs of the 20th Century. Many of the contract workers were recruited to be permanent immigrants. Indeed, the actual name of the Contract Labor Law was the "Act to Encourage Immigration". Moreover, throughout the brief period when contract labor was publicly authorized and the longer period when it continued informally, the nation essentially had an open-door immigration policy. Thus, the distinction between temporary workers and permanent immigrants was not really meaningful. If contract workers wanted to stay, they could and many did.

It was the Immigration Act of 1917 that laid the actual foundations for temporary worker policy. This statute was the most restrictive immigration legislation to be adopted by the nation at that point. Among its features were provisions that allowed the Secretary of Labor to waive prohibitions in the Act (e.g., the need to pass the literacy test) for aliens from the Western Hemisphere who applied for temporary admission as workers. Thelegislation did not specify exactly what conditions were required to exist for the Secretary to exercise these powers. But, when the United States declared war on Germany in April, 1917, it was only a month later that the Secretary invoked the temporary worker provisions. He was responding to petitions from agricultural interests in the Southwest which predicted extensive shortages of farm labor [U.S. Senate, 1980:7]. Nationwide, the unemployment rate is estimated to have been 4.6 percent in 1917 and to have declined to 1.4 percent in 1918 [Lebergott, 1964:512]. The program subsequently admitted 76,802 Mexican workers who were employed mainly in agriculture in the Southwest. Some workers, however, were also admitted for non-agricultural work on the railways. A few thousand additional workers from the Bahamas and from Canada were also admitted for other non-agricultural work. When the war 
ended in November, 1918, the use of the non-agricultural workers ceased but workers in agriculture continued to be employed until March, 1921 when the program was finally terminated except for certain "meritorious cases" that were permitted until 1922. Fewer than half of the total number of workers returned to Mexico [Kiser, 1972:130]. Rather than end reliance on Mexican workers, however, the program actually led to greater dependence on these workers in the Southwest in subsequent years albeit often as illegal immigrants [Scruggs, 1960:319].

The involvement of the United States in World War II again led to pleas from agricultural interests in the Southwest for a revival of a temporary workers program to meet projected labor shortages. In 1942 the nationwide unemployment was 4.7 percent but it declined rapidly to 1.9 percent in 1943; 1.2 percent in 1944; and 1.9 percent in 1945 . Initially, in 1942 the provisions of the Immigration Act of 1917 were used to activate such a program until special legislation was enacted under an omnibus appropriation bill known as P.L. 45 in August 1942. Under this legislation, the Mexican Labor Program was created (more popularly referred to as the "bracero program"). P.L. 45 was formally extended following the end of World War II until December 31, 1947 although it continued to function informally and unregulated until 1951. In 1951, with the nation again embroiled in a major military conflict in Korea, the bracero program was offically revived under P.L. 78. The national unemployment rate for 1951 was 3.3 percent and it fell further to 3.1 percent in 1952 and to 2.9 percent in 1953. When the Korean Conflict ended in 1953, however, the revived bracero program continued as the result of three separate legislative extensions before it was unilaterally terminated by the United States on December 31, 1964.

The bracero program was authorized under special congressional legislation that was separate from the nation's immigration statutes. The details concerning the bracero program have been carefully researched [Craig, 1971; Galarza, 1964; and Garcia y Griego, 1983]. Suffice to say, the program at its height in 1956 involved almost one-half million Mexican workers a year. There were extensive charges of corruption by Mexican officials in the selection of the participants. Although the program mandated wage protections as well as an extensive array of assurances for medical care, transportation, meals at reasonable costs and free housing, many of these protections were inadequately, if at all, provided by U.S. employers. The program adversely impacted both wage and employment opportunities of citizen workers - many of whom were Chicanos [Briggs, 1973:29; and President's Commission on Migratory Labor, 1951:59]. The bracero program served to expose the Mexican workers to the broad range of employment opportunities, higher wages and better working conditions that the U.S. labor market offered relative to Mexico. As a consequence, it institutionalized the process whereby many former bracero workers - having been exposed 
to, the U.S. labor market continued to seek work in the U.S. in subsequent years as illegal immigrants after the program ended.

It was also during World War II that the United States established a similar temporary worker program with various governments in the British West Indies [U.S. Senate, 1978]. Known as the British West Indies Labor Program (BWI), it was designed primarily to meet demands of East Coast agricultural interests in that they too were experiencing labor shortages. Although its scale was considerably smaller - involving about 24,000 workers at its peak, it did exert a significant impact on the local labor markets where it functioned. The BWI program, unlike the bracero program, also made workers available for non-agricultural employment during the war years. The BWI program functioned from 1943 to 1947 under the same umbrella legislation as the bracero program - P.L. 45. From 1947 to 1952, after P.L. 45 expired, the BWI program continued to operate but it was converted into a temporary worker program under the aegis of the Immigration Act of 1917. A presidential review of the BWI program in 1951 led to extensive criticism of the administration of the program for its "lack of vigilance for the protection of living and working standards" of the participants [President's Commission on Migratory Labor, 1951:58].

In 1952, during the midst of the Korean Conflict, the Immigration and Nationality Act was passed. Among its features were significant changes in the nation's temporary worker policy. The Act established the principle whereby all non-citizens entering the United States must be classified as immigrants or non-immigrants. The nonimmigrant classification, in turn, listed twelve separate classifications - each subsequently known by the letter and number specified in the legislation. One of these provisions section H-2 - established the classification "other temporary workers". It is this grouping of nonimmigrants - the $\mathrm{H}-2$ workers who are given permission to be admitted only for work that is itself temporary in nature - that has over the years generated the most controversy. By creating a special mechanism for the admission of temporary workers, this legislation has replaced the need to rely on the provisions of the Immigration Act of 1917. The new legislation did, however, specifically repeal the Alien Contract Labor Act of 1885 with its ban on the use of contract labor. As for the BWI program, it was simply subsumed under the H-2 rubric. The employers of BWI workers successfully resisted efforts to incorporate their program into P.L. 78 that had revived the bracero program in 1952. They correctly saw that P.L. 78 was outside the regular immigration laws. They favored legislation that would be securely authorized within the structure of the nation's basic immigration statutes.

In theory, H-2 workers can only be admitted if unemployed citizens and permanent resident aliens cannot be found to perform the needed job. There are procedures established by the Department of Labor that require prior efforts to recruit citizen workers as well as to pay wages and to provide 
benefits based upon prevailing labor market conditions. The highest number of $\mathrm{H}-2$ visas that have been issued was in 1969 when $69,228 \mathrm{H}-2$ workers were admitted. Since then, the number has declined to about 23,000 to 25,000 visas a year, (See,Appendix). Within the H-2 category, about one-half of those admitted in recent years have been agricultural workers (mostly as sugar cane harvesters in Florida, apple pickers in New York and Virginia, and loggers in Maine). Most of the remainder are various professional and technical workers who are generally of a lower status than those admitted under the separate $\mathrm{H}-1$ classification of temporary workers of "distinguished ability or merit". Most of the non-agricultural $\mathrm{H}-2$ workers are lesser known writers, musicians, artists, entertainers, and athletes. The remainder cover the spectrum of occupations.

There have been two infamous applications to the $\mathrm{H}-2$ program in the micro labor markets of the U.S. territories of Guam and the Virgin Islands. In both instances, the $\mathrm{H}-2$ worker concept was seriously perverted by the failure to restrict the occupations in which these workers found employment and the time duration (which extended into years) they were allowed to remain employed on these islands. As a consequence, $\mathrm{H}-2$ workers adversely impacted the local wage and employment conditions as well as served to foster extensive illegal immigration by other workers from their same homelands before the programs were terminated [Briggs, 1984:109-113; U.S. House of Representatives, 1975; and U.S. House of Representatives, 1979].

It has been the use of $\mathrm{H}-2$ workers in agriculture that has, over the years, generated the most controversy. These criticisms have cut deeper than simply the issue of whether these foreign workers take jobs that might otherwise be available to citizen workers and permanent resident aliens. They have centered upon the operational features of the program that are considered to be unfair and, if applied to citizens, would be illegal. They are unfair because employers do not have to pay social security taxes or unemployment compensation payroll taxes on $\mathrm{H}-2$ workers that would be required if citizens were hired. The program also permits actions that would be illegal elsewhere in the economy because of the use of industry blacklists; the fact that workers are subject to arbitrary treatment and dismissals; and the use of a system whereby employers are permitted to request back by name the following year only 60 percent of those workers hired during the current year (which means that workers are forced to compete with each other to curry the favor of employers [U.S. House of Representatives, 1983]). The agricultural $\mathrm{H}-2$ program is especially attractive to employers because it serves to guarantee the employer a set work force. If any worker is dismissed, dissatisfied, injured, or ill, he will be replaced by another grateful worker who is selected by his government - often under terms that require kickbacks or are the result of political favoritism.

Each manifestation of a temporary worker program was introduced at a 
time when the nation was at war. Under these circumstances when unemployment was low and labor shortages were real, the need for such undertakings seemed logical. In every instance, the programs continued long after the military emergencies ended. In peacetime, the logic of their existence-especially when aggregate unemployment has been high - ceases to be compelling. Instead, the conditions under which foreign workers are employed seem only to be beneficial to the self-interest of employers who find such workers highly desireable when in comparison to citizen workers. Under the auspices of these programs, they can obtain a relatively more docile labor force that is almost impossible to unionize and who can be treated in an arbitrary manner with impunity. It is not surprising, therefore, that an employer attitude study in the San Diego, California area in 1982 towards the prospects of a new foreign worker program showed strong positive support [Nalvern and Frederickson, 1981]. The study found that the employers did not fear that they would go out of business if they had to pay competitive wages for citizen workers or that they could not find available citizen workers at prevailing wage rates. Rather, the employers simply believed they could make more profits by paying lower wages as the result of hiring foreign workers than if they had to seek citizen workers.

The most tragic aspect of the on-going efforts by fruit and vegetable employers to maintain and to expand their sources of cheap farm labor is the fact that the tactic "spells disaster in the long run" for the industry [Martin: 1983,59]. This is because the debate over the need for foreign temporary workers has diverted attention away from the greater challenge to the survival of the domestic agricultural industry: foreign product competition. Access to cheap foreign labor sources may benefit the industry in the short run. But their availability, as Philip Martin (1983) has persuasively argued, blinds agricultural interests to the imperative for rapid technological change if they are to compete with foreign producers who can still rely upon far cheaper labor supplies. If it is the case that citizen farm workers cannot be found at competitive wages and working conditions, Martin shows that it would be preferable to accelerate the mechanization of the industry than to rely upon a self-defeating addiction to labor-intensive production techniques.

\section{THE EMERGENCE OF A PROPOSED NEW ROLE}

Although the issue of illegal immigration into the United States has existed for as long as there have been efforts to restrict immigration, the nation has only periodically sought to confront the problem. One effort was the infamous border sweep associated with "Operation Wetback" in 1954-5 and another was the unsuccessful legislative effort to adopt employer sanctions against hiring illegal immigrants in the early 1970s. Some portion of the illegal immigrant flow - especially from Mexico - has involved persons who are 
not interested in permanent settlement. Instead, this sub-group of the illegal immigrant population constitutes an "unofficial" temporary labor force that seeks employment in such seasonal industries as agriculture, construction, recreation, food services, and lodgings. In the off-season, these workers typically return to their homelands. Hence, as part of the quest to find a comprehensive solution to the illegal immigration problem, proposals have been made to enlarge the nation's official temporary worker policy so as to legalize the status of these illegal immigrants by making them nonimmigrant workers.

Support for this new role for temporary worker policy has come from a number of immigration scholars. W.R. Böhning [1979 and 1984], for instance, cited the post World War II experience of Western Europe with "guestworkers" as an example that the U.S. should follow. Charles Keely [1979:60-2]- offered a similar proposal. Keely, however, coupled his suggestion for a new temporary worker program with the requirement that the United States also sharply increase its labor standard enforcement activities as well as adopt employer sanctions to discourage other illegal immigrants from being employed. Likewise, in response to a specific request by President Jimmy Carter to the National Commission on Manpower Policy in 1977, a special study was prepared for the Commission by Edwin Reubens on the use of temporary worker programs as a means of reducing illegal immigration. Reubens subsequently offered two alternatives: one was to create an entirely new temporary worker program and the second was to expand and improve the existing H-2 program [National Commission on Manpower Policy, 1979]. The new temporary worker proposal called for a program that would be significantly larger than the present $\mathrm{H}-2$ program in terms of the number of workers permitted to enter each year. These workers would be restricted to those jobs of low skill, low paid work which currently are often filled by illegal immigrants [National Commission on Manpower Policy, 1979:59]. The workers could work in the United States for one year with possible contract renewals for up to three more years. They would not be able to bring their families with them. After their contract period expired, they would have to return to their homeland. Reubens pointed out that, to be effective in absorbing jobs currently held by illegal aliens who were only temporarily in the United States, the program would have to enroll "hundreds of thousands" of temporary workers a year. The alternative proposal suggested by Reubens was to keep the $\mathrm{H}-2$ program at its present level but to enhance procedures to recruit citizen workers for low wage jobs before turning to the $\mathrm{H}-2$ option. This would be done by improving job information channels, upgrading existing jobs, enhancing mobility, and providing more training for low skilled workers. After studying the Reubens proposal, the Commission wrote to the Secretary of Labor that it was "strongly against" any new 
expanded H-2 program [Ginzberg, 1979:2]. As for the existing agricultural $\mathrm{H}-2$ program, the Chairman of the Commission wrote:

With respect to the $\mathrm{H}-2$ issue, the beginning of wisdom is to recognize that farmers are a vocal political force and that one should not tangle with them unless one must, because of their ability to weaken those in office who oppose them. It seems to me therefore the better part of wisdom for the Secretary of Labor to suffer with the present awkward program rather than to attempt any radical revision that would bring these small but powerful special groups down on them. [National Commission for Manpower Policy, 1979: 109-110].

The proposals by Böhning, Keely, Reubens and a few others are essentially conceptual sketches. Each only scratched the surface of the details of how such an undertaking would actually work. What is of importance about these proposals was the fact that each was seriously proposed as a way to address the problem of illegal immigration in the United States.

In the meantime, Congress - which was reluctant to act upon a series of legislative reforms offered by President Carter in 1977 to address illegal immigration - created the Select Commission on Immigration and Refugee Policy to study all aspects of the nation's immigration policy. In its final report issued in 1981, the Select Commission acknowledged that the extant H-2 program was deserving of extensive criticism but that the continuation of the program is necessary and preferable to the institution of any new program [Select Commission, 1981:227]. The Select Commission did suggest that the administration of the H-2 program be "streamlined" and, to remove any inducement for employers to favor $\mathrm{H}-2$ workers over citizens, that employers be required to pay both social security and unemployment compensation payroll taxes for $\mathrm{H}-2$ workers. The Select Commission, however, advised that no new temporary worker program be established as part of a possible strategy against illegal immigration [Select Commission, 1981:45].

By the time the Select Commission issued its final report, the Reagan Administration had replaced the Carter Administration. As the Reagan campaign had ignored the immigration issue, it had no pre-established position. Hence, a task force was established to prepare a response to the Select Commission's recommendations. On July 30, 1981, the task force issued its report. In it, there was no mention made of the H-2 program but the report did call for the creation of an "experimental temporary worker program for Mexican nationals" [U.S. Department of Justice, 1981: 5]. Labeling it as a two year "pilot program", 50,000 Mexican nationals a year would be admitted to work in the United States as temporary workers. If the pilot program worked satisfactorily, it was understood that the number of temporary workers could subsequently be increased dramatically [Nalvern 
and Frederickson, 1982:1]. The Reagan proposal for a new temporary worker program was linked to a comprehensive effort to combat illegal immigration that included employer sanctions and amnesty proposals. Thus, the Administration's proposal revived the idea that temporary worker policy should be part of the nation's effort to attack the problem of illegal immigration.

\section{INVOLVEMENT IN IMMIGRATION REFORM IN THE 1980s}

The Reagan Administration's position - including the pilot program for temporary workers - was subsequently drafted into a bill known as the Omnibus Immigration and Control Act of 1981. For a variety of reasons, however, this bill was so deficient in its content that it was never acted upon by Congress. Instead, a bi-partisan bill was prepared by Senator Alan Simpson (R-Wy) and Congressman Romano Mazzoli (D-Ky) which they jointed introduced to Congress in 1982. It was a comprehensive attempt to reform all phases of the nation's immigration system.

The Simpson-Mazzoli bill of 1982 did not mention a new temporary worker program but it did adhere to the suggestions of the Select Commission by proposing ways to make the $\mathrm{H}-2$ program more accessible to employers. As previously discussed, the $\mathrm{H}-2$ program has traditionally been used by agricultural employers along the East Coast but not by those in the Southwest. The growers in the Southwest have, since the termination of their bracero program, relied extensively upon illegal immigrants to pick their speciality produce of vegetables and fruits. Southwestern growers have felt that the federal government does not approve employer petitions fast enough to meet their needs to harvest these perishable crops. The move to liberalize the H-2 program was seen as a way to ween Southwestern growers away from their dependence on illegal immigrants whose employment would be illegal if employer sanctions were adopted.

The Simpson-Mazzoli bill easily passed the U.S. Senate but in the House of Representatives it encountered stiff opposition. One of the key topics that served as a lightening rod to rally opponents to the bill were the suggested $\mathrm{H}-2$ changes. The H-2 provisions of the existing law place no ceiling on the number of temporary workers who can be admitted in any year. Thus, the number of $\mathrm{H}-2$ workers can easily increase at any time if the approval process of employer applications is expedited and if any particular Administration is sympathetic. The proposed reform bill would have allowed the U.S. Department of Agriculture - a traditionally employer-oriented agency of government - to share responsibility with the U.S. Department of Labor for the operation of the program. Moreover, the Attorney General would still have been allowed to overrule any negative decision made by these agencies. Thus, organized labor (i.e., the AFL-CIO) which supported most of the bill joined with many Hispanic organizations to assail both the proposed changes 
and the retention of the entire $\mathrm{H}-2$ program. As the president of the Mexican American Legal Defense and Education Fund (MALDEF) charged: "The Simpson-Mazzoli $\mathrm{H}-2$ program is really just a replay of the bracero program" that would actually "foster" illegal immigration just as the old program had done [Joaquin G. Avila, 1982: A-26]. As action on the bill had been delayed until the end of the congressional session, the discord over the temporary work provisions contributed to the bill's death on the floor of the House in mid-December 1982.

In 1983, somewhat different versions of the bill - reflecting the actions taken during the previous session by each house of Congress - were re-introduced. Again, the Senate version did not mention any new temporary worker program but it did provide for easing employer accessibility for $\mathrm{H}-2$ workers. The House version also eased the $\mathrm{H}-2$ provisions but, in addition, it called for the creation of a three year transitional temporary worker program that would permit agricultural employers time to adjust to the proposed future ban on the employment of illegal immigrants. During the first year the bill took effect, agricultural employers could still hire a labor force that was composed entirely of illegal immigrants; during the second year, 67 percent of the employer's work force could be illegal immigrants; during the third year the percentage was reduced to 33 percent; and by the fourth year, the transitional program would be terminated. Under this program, the grower would have been required to notify the Department of Labor of the number of illegal immigrant workers who were hired and a special permit would have been issued for each designated foreign worker. No ceiling was placed on the number of illegal immigrant workers who could be hired so the precise number of foreign workers involved would not have been known. Conceivably, the number could have been as high as several hundred thousand workers. Opponents of the transitional worker program argued that it represented a "contradiction" to the expressed goals of the immigration reform movement since it, like the other temporary worker programs, would only serve to encourage more Mexican workers to come and to remain in the United States [League of Latin American Citizens, 1983:5]. They also opposed the program because, unlike the $\mathrm{H}-2$ and earlier temporary worker programs, the transitional program contained virtually no worker protection requirements nor did it provide any monitoring mechanism.

The U.S. Senate overwhelmingly passed its reform bill in May, 1983. In the House, the bill languished for over a year before it finally received a rule that would permit floor debate in June, 1984. During the ensuing floor debate, an amendment was added to create an entirely new temporary worker program for agricultural workers. Proposed by Congressmen Leon Panetta (D-Cal.) and Sid Morrison (R-Wash.), it would have permitted temporary farmworkers to be admitted to the United States to harvest fruits 
and vegetables for up to eleven months a year. Unlike agricultural $\mathrm{H}-2$ workers, these workers would be free to move from employer to employer within a specified geographical region. The program had no fixed duration. The number of temporary workers to be admitted each year would be left to the Attorney General to decide after consultation with the Secretaries of Labor and of Agriculture. The Attorney General would have had as little as 72 hours to respond to urgent requests from employers for such workers. As the Attorney General and the Department of Justice have no expertise in labor market analysis, it was believed by many observers that decisions especially those requiring quick notice - would likely be based upon political rather than economic considerations. It was estimated that the number of such temporary workers could have easily totalled as many as a half-million workers a year [Pear, 1984: B-5]. Agricultural interests made it known that inclusion of this open-ended program was their bottom line for support of the overall immigration bill. Senator Simpson would later bitterly call this action by agricultural employers "the epitome of greed" [Hume, 1985: 64]. On the other hand, the amendment greatly strengthened the hand of opponents to the entire bill. Congressman Henry Gonzales (D-Tex.) charged that the amendment "would even offend a slave driver" since it did "not even provide the skeletal labor protections that existed under the infamous bracero program" [New York Times, 1984, A-20]. He labeled the amendment as a "rent a slave" device. The AFL-CIO, which until this point had favored the bill's passage, suddenly withdrew its support. The amended bill finally did pass the House but only by a narrow five vote margin. As events were to reveal themselves, the entire bill ultimately died in a Senate-House conference committee on October 11, 1984. While other issues were involved, the temporary worker provisions were a major part of the explanation for the loss of key support needed to pass the bill.

Having witnessed for the second time the process by which temporary worker policy had contributed to the demise of immigration reform, the Reagan Administration in January, 1985 initiated a plan that might remove this contentious issue from the next legislative attempt to pass immigration reform. Namely, the Administration began considerations to liberalize the $\mathrm{H}-2$ regulations unilaterally by administrative action [Pear, 1985a: A-1]. The regulation changes, once published in the Federal Register and after public comments were received and responded to, could be issued by the INS as final rules which carry the full force of law. Among the major planned changes were the following: employers would no longer have to make extensive searches for citizen workers if the U.S Department of Agriculture declares that "perishable crops are in danger due to unforseen emergency"; H-2 workers could remain in the United States for 20 days after they had completed one job to look for work with another agricultural employer (under existing law they could not look for work elsewhere and would have 
to return to their homeland when their original job was completed); and employers would be able to pay a housing allowance to $\mathrm{H}-2$ workers in lieu of providing actual housing as is the prevailing policy. The revised rules would also specify that employers of $\mathrm{H}$-2 workers would have to give consent to INS officials to enter their fields and to inspect their records to check for illegal immigrants without meeting the current requirement to secure a court warrant in advance. Any agricultural employer who was found to have a pattern of employing illegal immigrants would be barred for one year from use of temporary workers.

Agricultural employers, when informed of these suggested changes, acknowledged that they did "demonstrate a sensitivity to the needs of agriculture". Nonetheless, they were still not satisfied [Pear, 1985a: A-1]. They feared that what one Administration may change by regulations, a later Administration could reverse by regulation. Hence, they made it clear that even if the changes were made, they still intended to press for statuatory enactment of these principles. Likewise, the traditional opponents to temporary worker policy were quick to voice their opposition to these administrative proposals. The United Farm Workers (AFL-CIO) stated that they were against "every" change that would make it easier to admit temporary workers under any program. Likewise, MALDEF voiced its absolute opposition to these changes because they permitted exploitation of foreign workers and they would undermine efforts to unionize farm workers. Hence, it seemed inevitable that the $\mathrm{H}-2$ revisions would again become part of the debate over immigration reform despite these efforts to short-circuit the issue. Because no one seemed sympathetic to this alternative, the Reagan Administration has not yet promulgated any of these changes.

Meanwhile, for the third time in four years, Senator Simpson introduced in May 1985 another immigration reform bill. It focussed almost exclusively on the issue of illegal immigration. The lingering problems associated with legal immigration, refugees, and asylees were simply put aside. There was no mention of a new temporary worker program but the changes in the $\mathrm{H}-2$ program that would make it easier for employer application to be approved and the three-year transition program for agricultural employers were both re-introduced. When the bill went on the Senate floor for debate in September, 1986, no feature of the bill caused more rancor than the topic of temporary workers. On September 12, Senator Pete Wilson (R-Cal.) offered an amendment that would create a new temporary worker program in addition to the aforementioned features already in the bill. The Reagan Administration was divided over its views on the Wilson amendment. The Immigration and Naturalization Service (INS) and the Department of Labor publicly opposed the amendment but the Department of Justice was sympathetic. Avoiding a specific endorsement of the Wilson amendment, the Administration issued a bland homily that called for a "self-financed, limited seasonal worker program 
which would provide field harvest labor for perishable commodities" [Pear, 1985b: A-17]. When the vote was taken, the Wilson amendment failed, 50 to 48. A week later, however, the Senate reversed itself and, on a 51-44 vote, added the amendment to the bill. The only significant difference between the defeated amendment and the adopted amendment was that the latter had an explicit limit of 350,000 temporary workers who would be allowed in the United States at any one time during the first three years. This cap was designed to respond to the charge that the original bill would have been an open-ended authorization for seasonal workers. After three years, the amiendment specified that the Attorney General could set a new ceiling based on the experiences of the program. A subsequent amendment, offered by Senator Paul Simon (D-Ill.), however, was later adopted that would have limited the life of this program to 33 months unless a specific new law was passed by both houses to extend it. In this amended form, the entire immigration reform bill was passed overwhelmingly by the Senate on September 19, 1985.

Thus, of all the controversial features contained in the Simpson bill employer sanctions, amnesty to most illegal immigrants already in the country, and reimbursements to states by the federal government for the increased social costs associated with the amnesty program - it was the temporary worker provision that stirred up the most passionate debate. Senator Wilson argued that there would be crops rotting in the fields if the temporary worker program was not included and if Southwestern growers could no longer hire illegal immigrants. Senator Metzenbaum (D-Ohio.), who opposed the program painted a scene of foreign workers "sleeping in ditches and plastic bags" in the rural areas where the temporary workers would toil. His conclusion was based on the provisions of the Wilson program that would allow growers to provide a housing allowance in lieu of actually providing housing itself. After passage, a MALDEF spokesman stated that with the Wilson amendment "the growers have been able to turn an immigration bill into an agricultural worker bill" [Pear, 1985c: A-21]\#. By all accounts, the Wilson proposal offered fewer worker protections and required less from employers than any temporary worker program that had ever before been adopted by the United States. A comparison of many of the key features of the much criticized bracero program with the Wilson program shows the bracero program to have been far more concerned about protecting both citizen and foreign worker rights and welfare [Congressional Record Senate: 1985, S11686]. For instance, the Wilson program did not require domestic recruitment as a prerequisite for approval of applications of foreign workers and it did not require that the Department of Labor certify there is a shortage of U.S. workers. It did not guarantee to U.S. workers that employment terms at least be comparable to those offered foreign workers. Unlike the bracero program, the Wilson program did not guarantee foreign workers 
a written contract or guarantee a minimum period of work or guarantee that meals would be provided at cost. Clearly, the Wilson program assumed extensive employer goodwill in the conduct of the program - a conclusion that past history does not support.

As has been the case in the two earlier attempts to pass immigration reform, the House of Representatives waited for the Senate to go first. Unlike the past, advocates of immigration reform in the House did not co-sponsor the bill that had been introduced in the Senate. Instead, the House version - introduced jointly in September 1985 by Congressmen Peter Rodino (D-N.J.) and Romano Mazzoli (D-Ky) - differed significantly in many of its key elements pertaining to ways to address the illegal immigration problem. For present purposes, however, it is sufficient to say that the bill did propose to ease the administrative regulations pertaining to the agricultural $\mathrm{H}-2$ programs and it also contained provision for the three year transitional program for illegal immigrants employed in agriculture. During the mark-up of the bill by the immigration subcommittee of the House Judiciary Committee, however, the transitional temporary program was deleted. The original bill, however, did not contain any mention of a new temporary worker program. Indeed, Congressman Rodino indicated that he was "deeply disappointed" by the addition of the Wilson amendment to the Senate bill and he indicated that the Senate action would greatly complicate the process of ultimately passing any immigration reform [Pear: 1985c, A-21.

For ten months after the Senate passed its version of immigration reform, there was no visible action taken by the Judiciary Committee of the House of Representatives. Behind the scenes, however, lengthy negotiations took place over the issue of the temporary worker provisions contained in the draft and possible additional amendments. Involved were proponents of farm workers; supporters of agricultural business interests; and advocates of a compromise solution between these two contending groups in order that the immigration reform bill could be debated. Finally, in early June 1986, Congressman Charles Schumer (D-N.Y.), a leader of the compromise group, announced that agreement had been reached on a plan to end the stalemate [Pear, 1986a, A-19]. Essentially, it stated that the Attorney General could grant lawful permanent resident status to any illegal immigrant who could prove that he had been working in perishable agriculture for at least 20 full days from May 1, 1985 to May 1, 1986. If some of these workers subsequently quit working in agriculture, the proposal also provided a means to "replenish" the labor supply with additional illegal aliens who could also subsequently become resident aliens.

The rationale for providing the opportunity for those illegal immigrants who have been recently employed in southwestern agriculture to rapidly become aliens was multifold. Its primary intention was to overcome the 
opposition of southwestern growers to the possibility of employer sanctions that would make several hundred thousand of their current employers ineligible to be retained. As discussed earlier, these agricultural employers continued to be adamant in their assertion that citizen workers could not be attracted to meet their seasonal demand for workers to pick perishable crops. Of equal importance was the fact that the amendment also overcame the fears of supporters of immigration reform who opposed the idea of a new guestworker program as provided by the Wilson Amendment. By allowing those illegal immigrants who have been employed in agriculture to have a unique right to obtain resident alien status by virtue of their past employment record and, if they choose, to become naturalized citizens later, these workers could now have most of the protections and freedoms available to nonagricultural citizen workers. Given resident alien status, these workers would be able to qualify for some social entitlement programs in the off-season. Moreover, they would not be forced to remain agricultural workers (i.e., they would not be tied to employers as "serfs") if better job opportunities should become available to them. For those who remained in agriculture, it would be easier for them to be unionized if they knew that they could remain permanently in the United States. An additional attraction of the Schumer Amendment to growers was that it also included a complex provision that would allow for "replenishment" of farm workers after 1989 for those newly legalized aliens who subsequently exercise their prerogative to find employment outside of the agricultural industry. Thus, this ingenious compromise provided a balance between the demands of growers for an adequate supply of labor and the insistence of union and Hispanic groups that agricultural workers be protected from the gross opportunities for exploitation that have been traditionally associated with temporary worker programs in the past.

The immediate reaction to the Schumer Amendment, however, was far from positive. Indeed, it became an immediate subject of intense controversy. Nonetheless, it accomplished its primary purpose: it broke the logjam in the House Judiciary Committee that had prevented the bill from reaching the floor. On June 25, 1986 the Committee voted 19 to 16 to add the amendment, with only slight modification, to the bill. The revised version specified that permanent resident alien status would be provided to illegal immigrants if they had worked in agriculture for U.S. employers for not less than 60 days during the 12 months that preceded May 1, 1986. At this point, however, Congressman Mazzoli threatened to abandon the entire bill. Calling the amendment "unparalleled, unprecedented, and unacceptable", he pessimistically predicted that "passage of the Schumer Amendment ensures the bill's doom" [Daily Labor Report, p. A-3]. Nonetheless, the next day the Judiciary Committee voted 25 to 10 to send the amended bill to the floor of the House. 
For a time, it seemed that Mazzoli's prediction would prove true. The bill was not taken up by the House Rules Committee until late September 1986. When it was, House Minority whip, Trent Lott (R-Miss), called the Schumer Amendment "the most controversial issue" in the entire bill and Representative D-Lungren (R-Cal.), a strong supporter of immigration reform, called the amendment "an abomination" that would "kill the bill" [Pear, 1986c, p.31]. When the debate rules were established, however, they forbade any amendments to be made to the fragile terms of the Schumer Amendment. The other key provisions of the bill - employer sanctions and amnesty could be debated on the floor and were subject to possible deletion - but not any feature of the foreign agricultural worker proposal could be discussed. Its fate was linked to the passage of the overall bill.

A resolution to adopt the debate rules which contained this ban was offered on the floor of the House on September 26, 1986. By a vote of 202-180 the resolution on the rules was defeated. With the Congress planning to adjourn the next week, the prospects for an immigration reform bill appeared to be lost again. All fingers of blame were immediately pointed to the provision in the rules that prohibited debate on the Schumer Amendment [Pear, 1986d, p.8]

\section{PASSAGE OF THE SIMPSON-RODINO ACT}

Amid an outcry of critical editorials by the nation's print media in the days that immediately followed the defeated vote on the rules, a completely unexpected window of opportunity for the resurrection of immigration reform was suddenly created. The Congress had not yet passed a military appropriation bill which contained several controversial foreign policy provisions. In addition, the President had not yet signed another controversial bill pertaining to the creation of a large environmental "superfund" and there was congressional fear that, if Congress adjourned, the President would kill the bill with a pocket veto. It was at this point that it was publicly announced on October 7, 1986 that President Reagan would meet personally with Soviet Premier Mikhail Gorbachev in Reykjavik, Iceland on October 11 and 12. Hence, Congress could not force the showdown on the appropriation bill while the President was out of the country at a summit meeting on the possibility of setting an agenda for nuclear disarmament. Thus, an unexpected pause in its planned activities was forced on Congress. Adjournment had to be postponed. Behind the scenes negotiations on the immigration bill were'quickly renewed. A minor change was made in the provisions of the Schumer Amendment. The number of days an illegal immigrant who had worked in agriculture in the year preceding May 1, 1986 to be eligible for eventual adjustment of status to become a resident alien was increased from 60 to 90 days. Given the inability to act on the other critical issues, the Houses of Representatives reversed itself on October 9, 1986 and voted 278 to 
129 to accept the debate rules. Fourteen amendments would be debated but there could not be any debate on the Schumer provisions. A marathon session began and, late in the evening of October 9, 1986, the House passed the Immigration Reform and Control Act (i.e., the Simpson-Rodino bill) by a vote of 230 to 166 .

A Senate-House conference committee was constituted and it reached agreement on October 14, 1986. In the conference, the Senate proposals for the Wilson Program and for the transitional farm worker program were deleted; the House proposal for the Schumer provisions were retained. On October 15, 1986, the House voted 238 to 173 to accept the conference report and the Senate did likewise on October 17, 1986 by a vote of 63-24. President Reagan signed the historic bill into law on November 6, 1986.

\section{THE BYPASS OF THE BARRIER TO IMMIGRATION REFORM}

The Schumer Amendment, which had formerly been cited as being "the villainous obstacle", was now hailed as being the "miraculous compromise" that had made immigration reform possible. What has been lost in the euphoria surrounding the passage of the Simpson-Rodino bill, however, is the fact that it was not until the temporary worker issue was essentially removed from the bill by the creation of a program for permanent adjustment of status - a "second amnesty program" is probably a better description of the Schumer Amendment - that the bill was able to pass. For as Representative Rodino clearly stated during the final vote on the conference report, "this program (i.e., the Schumer Amendment) has none of the elements of the old Bracero Program and can in no way be classified as a guestworker program". [Congressional Record - House: 1986, H 10585].

Under the adopted legislation, therefore, any illegal immigrant who had worked 90 days in the perishable agriculture industry during the twelve month period prior to May 1, 1986 can apply to a newly created category of being a temporary resident alien. These applications are to be made during the period from May 1, 1987 to November 1, 1988. After two years in this status, they may apply for adjustment to become lawful permanent resident aliens. After the customary five years as permanent resident aliens they can apply to become naturalized U.S. citizens. In addition, the law specifies for persons who meet the 90 day requirement for work in the year ending May 1 , 1986 and who also had worked 90 days in the perishable agriculture industry during the twelve months preceding May 1, 1985 and the twelve month period prior to May 1, 1984, they would only have to remain in the temporary status for one year. A cap, however, of 350,000 persons was placed on the number of persons who can be placed in this one year temporary resident status. The actual number of persons, however, who may be eligible for ultimate eligibility for adjustment to temporary status in the one year and 
two year program is unknown and will only be revealed as the illegal immigrants come forth.

In addition, the Schumer provisions note that, if after September 30, 1989 the Secretaries of Agriculture and Labor jointly determine that there is a shortage of seasonal farm workers, a replenishment program is permitted for the fiscal years 1990 through 1993. Representative Schumer expressed the belief that "the vast majority of them [i.e., the initial group of illegal aliens who can become temporary resident aliens due to their existing employment histories], an extremely high percentage of them, will continue to work in agriculture" [Pear, 1986b, D-22]. There is, of course, nothing to guarantee that his assessment is correct. The number of replenishment workers who would be admissible would be determined by a complex formula based on the number of seasonal workers whose status was originally adjusted and the demonstrated need for additional workers. The law does state that there shall be no replenishment if there is no determination that a shortage exists. Furthermore, the entire program is terminated in 1994.

As for temporary worker policy itself, the new law created a new $\mathrm{H}-2 \mathrm{~A}$ subcategory for foreign temporary agriculture workers. Such workers will no longer be admitted under any other Section $\mathrm{H}$ category. The $\mathrm{H}-2 \mathrm{~A}$ procedures will be streamlined to facilitate the operation of the program over what has hitherto existed for agricultural workers. It still requires employers to attempt to recruit domestic workers after they notify the Secretary of Labor at least 60 days before they anticipate a need for additional seasonal workers. The Secretary must give a decision on the need to admit H-2A workers within 20 days before the date that the workers are actually needed. If the Secretary determines that citizen workers are unavailable or if those deemed available prove to be unqualified, an expedited procedure for admitting $\mathrm{H}-2 \mathrm{~A}$ workers is specified. Guaranteed assurances pertaining to housing, compensation, travel, and subsistence costs that were available under the previous $\mathrm{H}-2$ program were also specified for $\mathrm{H}-2 \mathrm{~A}$ workers. One change that was added, provides that legal services are for the first time to be made available to $\mathrm{H}-2 \mathrm{~A}$ workers for disputes over work-related matters.

\section{CONCLUDING OBSERVATIONS}

For almost a decade, attempts were made to link temporary worker policy with legislation designed to curb illegal immigration. These efforts represented a new rationalization for an old policy that was of questionable validity even when applied in its traditional context. Historically, temporary worker policy had been implemented to meet manpower shortages during war times. The favorable conditions that these programs offer to employers has tended to exert a narcotic effect on their subsequent attitudes. They become quickly addicted to the programs since they do not have to compete as do 
employers in other industries to attract and to keep workers. Hence, the life of these programs tends to be prolonged well after the original justification for their existence ceases. Employers soon realize that temporary worker programs are essentially a form of wage subsidy that is authorized by the federal government. Hence, they seek to retain the programs by claiming that citizen workers are not available under the altered (i.e., depressed) market conditions that these very programs themselves created.

Likewise, the long history of the nation with temporary programs vividly shows that it is difficult to enforce contractual terms and labor standards for foreign workers when, as in the case of agriculture, the workers are dispersed among numerous employers over a wide geographical rural area. The longer programs operate, the more difficult it is to monitor and enforce protections. Perhaps during wartime emergencies when arguments for these undertakings have the greatest validity, these abuses could be tolerated as an unavoidable evil. As an on-going instrument of public policy in peacetime, they can only serve as an embarassment to the nation and as a form of exploitation for many of those who are employed under their auspices. Worker protections exist to safeguard all of those who toil to produce the output of the society. It should make no difference if the workers are citizens or whether they want to be protected. Temporary worker programs have shown that they cannot function without corruption both in the selection of foreign workers in their homelands and in the actual implementation of the program by employers in the United States. The fact that both the PanettaMorrison proposal in 1984 and the Wilson proposal in 1985 assiduously avoided concerns about job protections, program monitoring, or the availability of housing for foreign workers revealed their actual purpose: to serve as an employer recruiting device for cheap farm labor.

The addition of the Schumer Amendment did serve largely to remove the contentious temporary worker subject from the immigration reform drive. It must be clearly recognized that it is a "quick-fix". It is not a temporary worker program itself but, rather, a special amnesty program for illegal immigrant farmworkers and an agricultural labor gift for southwestern growers. It is a program that could never have been enacted on the basis of its own merits for it has none. By virtue of political trickery that denied both debate and a vote on its existence, it became a barnacle attached to the broader purpose immigration reform legislation that could not be removed. One can only hope that its operations are carefully monitored and that the predictable pleas of growers in 1989 for "replenishment workers" will be subjected to decisions based on demonstrated economic needs and not be another exercise of raw political witchcraft.

As for the revised and newly named H-2A program, it does provide requirements for housing and transportation as well as wage, legal aid and job protections. Hence, it is a preferable alternative to any of the temporary 
worker proposals contained in the early versions of the Simpson-Rodino bill that omitted these safeguards. But even the premises of this program during peacetime are still suspect. The H-2A program perpetuates a situation by which no citizen worker can compete with those workers provided under its auspices. Easing access to the $\mathrm{H}-2 \mathrm{~A}$ program will only enlarge the scope of the self-fulfilling prophecy of employers whereby they can contend that citizen workers are allegedly not available.

Historically, temporary worker programs, have contributed significantly to the immigration phenomenon. Once exposed to the U.S. labor market, some will not return home and others who do go back will later return as illegal immigrants when the programs end or they are not chosen to participate again. Thus, it remains to be seen if temporary worker policy will once again bedevil the new legislative effort to gain control of the illegal immigration problem.

\section{Appendix: H-2 Worker Data Problems}

As with every other dimension of the nation's immigration system, an appraisal of the size and occupational composition of the H-2 program for temporary workers is severely hampered by the gross lack of meaningful data. The U.S. Department of Labor performs the initial certification of the jobs for which employers are seeking foreign temporary workers. Tables 1 and 2 indicate the number of certifications granted to employers for agricultural (since 1971) and for non-agricultural H-2 workers (since 1976) respectively. These figures, however, do not indicate the actual number of $\mathrm{H}-2$ workers that were subsequently admitted to the United States. As noted in the tables, an employer may ultimately decide to fill only a portion of the approved jobs (or they may decide to fill none). Moreover, some $\mathrm{H}-2$ workers may have been contracted to work two or more certified jobs. Thus, the data can only provide a rough estimate of the maximum allowable number of $\mathrm{H}-2$ workers who could have been admitted in each year - not the actual number who were.

It is the Immigration and Naturalization Service (INS), however, that ultimately issues the visas that allow the $\mathrm{H}-2$ workers into the country. But, tragically, the INS has been unable since 1978 to produce any reliable data pertaining to the number of $\mathrm{H}-2$ workers. Relying upon unpublished material, INS officials can only produce "ball-park" estimates such as those cited in the body of this article as to the number of $\mathrm{H}-2$ workers being admitted to the United States in the 1980s. For instance, the author was told that INS believes that roughly 24,500 workers were admitted in Fiscal Year 1985. Of this number, they cannot even determine how many workers were employed in agriculture and how many were in non-agriculture. This is because 18,000 visa forms that were turned-in for processing did not have to have 


\section{TABLE 1}

Labor Certifications Granted for H-2 Workers in Agriculture and Logging OCCuPations, Fiscal Years $1971-1984^{a}$

\begin{tabular}{lc}
\hline Fiscal & $\begin{array}{c}\text { Number of Jobs } \\
\text { Certified }\end{array}$ \\
\hline 1971 & 21,893 \\
1972 & 21,423 \\
1973 & 20,138 \\
1974 & 20,634 \\
1975 & 16,499 \\
1976 & 15,231 \\
1977 & 15,281 \\
1978 & 15,441 \\
1979 & 18,283 \\
1980 & 18,371 \\
1981 & 17,953 \\
1982 & 19,779 \\
1983 & 19,506 \\
1984 & 20,071
\end{tabular}

Note: ${ }^{a}$ The number of jobs certified does not indicate the actual number of foreign workers admitted for employment. An employer may use only part, or none, of the certifications granted. Also some admitted foreign workers may work in two or more certified jobs.

Source: 1984 Annual Report: Labor Certification for Temporary Foreign Agricultural and Logging Worker (H-2's) U.S. Employment Service, Division of Foreign Labor Certifications, U.S. Department of Labor, (March 1, 1985), P. 2.

occupation of the worker filled-in. Consequently, the country-of-origin of H-2 workers is used by the INS as a crude proxy to deduce whether the workers were employed in agriculture or non-agriculture. Thus, if the workers were from the Caribbean Islands in general (as were 12,600 of these visa holders in 1985), and from Jamaica in particular (as were 10,500 of these visa holders in 1985), the INS says it is fair to conclude that most of these workers were employed in agriculture in the United States during that year. As for the remainder who came from other countries, it is not possible to draw any reliable conclusion about their occupational distribution.

INS officials apologetically acknowledge that they cannot provide what is needed most: an occupational distribution of $\mathrm{H}-2$ workers for any year since 1978. Aside from budgetary problems that hinder the effectiveness of most federal agencies, the problem, it seems, is a lack of priority given to research and policy issues within the agency itself. The INS is essentially a law 
TABLE 2

Labor Certifications Granted for Non-Agricultural H-2 Workers Fiscal YeARS $1976-1984^{a}$

\begin{tabular}{lc}
\hline $\begin{array}{l}\text { Fiscal } \\
\text { Year }\end{array}$ & $\begin{array}{c}\text { Number of Jobs } \\
\text { Certified }\end{array}$ \\
\hline 1976 & 5,984 \\
1977 & 4,442 \\
1978 & 3,481 \\
1979 & 6,085 \\
1980 & 12,542 \\
1981 & 10,585 \\
1982 & 8,904 \\
1983 & 6,649 \\
1984 & 4,056 \\
\hline
\end{tabular}

Note: a See, note on Table 2.

Source: Tabular material provided from records of the U.S. Employment Service (Tables 312 and 208), U.S. Department of Labor.

enforcement agency and its leadership hierarchy is staffed accordingly. The focus of available $\mathrm{H}-2$ record-keeping is on the individual with little concern manifested about the importance of aggregate information. For enforcement reasons, the records are kept on the basis of personal names of the individual $\mathrm{H}-2$ workers which introduces massive keying errors when any serious effort is made to tabulate aggregate data for policy evaluation.

The creation of the new H-2A category as a separate and distinct entity under the Simpson-Rodino Act should greatly overcome the data nightmares that have plagued efforts to assess the agricultural worker aspects of temporary worker policy. There is no assurance, however, that the new law will improve the usefulness of this data for non-agricultural temporary workers admitted under Section H provisions.

\section{REFERENCES}

Avila, J.

1982 "Simpson-Mazzoli Immigration Bill: Back to the Bracero Fiasco". New York Times. (October 1, 1982).

Böhning, W.R.

1984 "Guest Worker Employment - Lessons for the USA"? In Studies in International Labor Migration. Edited by W.R. Bohning. London: The Macmillan Press Ltd. Pp. 123-164. 
1979 Regularizing Undocumentos. Geneva: International Labor Organization.

Briggs, V.M., Jr.

1984 Immigration Policy and the American Labor Force. Baltimore: The Johns Hopkins University Press.

1983 "Foreign Labor Programs as an Alternative to Illegal Immigration: A Dissenting View". In The Border That Joins. Edited by Peter G. Brown and Henry Shue. Totowa, N. J.: Rowan and Littlefield.

1973 Chicanos and Rural Poverty. Baltimore: The Johns Hopkins University Press.

Congressional Record - Senate

1985 "Comparison of the Labor Protections Afforded Under the Bracero Program (P.L. 78) and the Proposed Wilson Guestworker Program". (September 18, 1985).

Congressional Record - House

1986 Conference Report on S1200. Immigration Reform and Control Act of 1986. (October 15.)

Craig, R.

1971 The Bracero Story: Interest Groups and Foreign Policy. Austin: The University of Texas Press.

Daily Labor Report

1986 "House Committee Clears Immigration Reform Bill". No. 124 (June 27, 1986). Washington: Bureau of National Affairs.

Galarza, E.

1964 Merchants of Labor: The Mexican Bracero Story. Charlotte, N.C.: McNally and Loftin.

Garcia y Griego, M.

1983 "The Importation of Mexican Contract Laborers to the United States, 1942-1964: Antecedents, Operation, and Legacy". In The Border That Joins. Edited by Peter Brown and Henry Shue. Totowa, N.J.: Rowman and Littlefield. Pp. 49-98.

Ginzberg, E.

1979 Letter to Secretary of Labor Ray Marshall from Eli Ginzberg. Chairman of the National Commission on Manpower Policy, dated May 1, 1979. [Copy in possession of author].

Hume, E.

1985 "Immigration-Law Overhaul Prospects Brighten, But Changes Are Likely and Obstacles Remain". Wall Street Journal. (January 29, 1985).

Kiser, G.C.

1972 "Mexican American Labor Before World War II". Journal of Mexican American History. 2: $122-142$.

League of Latin American Citizens

1983 "Analysis of Simpson-Mazzoli Legislation H.R. 1510". An open letter released by the League's Washington, D.C. office on July 21, 1983.

Lebergott, $\mathrm{S}$.

1964 Manpower in Economic Growth: The American Record Since 1800. New York: McGraw-Hill.

Martin, P.L.

1983 "Labor Intensive Agriculture". Scientific American. (October, 1983). Pp. 54-9.

Nalvern, J. and C. Frederickson

1982 "The Employer's View: Is There a Need for a Guestworker Program"? San Diego: Community Research Associates.

National Commission for Manpower Policy

1979 Temporary Admission of Foreign Workers: Dimensions and Policies. Washington, D.C.: National Commission on Manpower Policy. Special Report No. 34. 
New York Times

1984 "Bill to Curb Illegal Immigration: House Debates Reflect Diversity of Nation". (June 17, 1984).

Pear, R.

1986a "Schumer Offers Plan for Importing Farm Workers". Neu York Times. (June 10, 1986).

1986b "House Panel Approves a Work Plan for Aliens in Immigration Bill". New York Times (June 26, 1986).

1986c "House Panel is Setting Terms for Debate on Aliens". New York Times. (September 14, 1986).

$198 \dot{6}$ d "House Refugees to Consider Broad Bill on Immigration". New York Times. (September $27,1986)$.

1985a "U.S. Plans to Ease Alien Labor Rules". New' York Times. (January 27, 1985.

1985b "Senate Kills Plans on Alien Workers". New' York Times. (September 13, 1985).

1985 c "Senate Alien Bill Draws Criticism". Neu" York Times. (September 19, 1985).

1984 "House Votes Plan to Admit Aliens to Harvest Crops". New York Times. (June 15, 1984).

President's Commission on Migratory Labor

1951 Migratory Labor in American Agriculture: Report. Washington: U.S. Government Printing Office.

Scruggs, O.M.

1960 "The First Mexican Farm Labor Program". Arizona and The West. Winter, 1960. Pp. 319-326.

Select Commission on Immigration and Refugee Policy

1981 U.S. Immigration Policy and the National Interest. Washington, D.C.: U.S. Government Printing Office.

U.S. Department of Justice

1981 "U.S. Immigration and Refugee Policy". Washington, D.C. (July 30, 1981).

U.S. House of Representatives, Committee on the Judiciary

1979 The Use of Temporary Alien Labor in Guam. Washington: U.S. Government Printing Office.

1975 Nonimmigrant Alien Labor Program on the Virgin Islands of the Inited States. Washington: U.S. Government Printing Office.

U.S. House of Representatives, Committee on Education and Labor

1983 Job Rights of Domestic Workers: The Florida Sugar Cane Industrv. Washington: U.S. Government Printing Office.

U.S. Senate, Committee on the Judiciary

1980 Temporary Worker Programs: Background and Issues. Washington, D.C.: U.S. Government Printing Office.

1978 The West Indies (BWI) Temporarv Alien Labor Program: 1943-1977. Washington: U.S. Government Printing Office. 